\begin{tabular}{|l|l|l|l|l|}
\hline Share: Social Work Jurnal & VOLUME: 8 & NOMOR: 2 & HALAMAN: $203-210$ & $\begin{array}{c}\text { ISSN: } 2339-0042(\mathrm{p}) \\
\text { ISSN: } 2528-1577(e) \\
\text { Doi: } 10.24198 / \mathrm{share.v8i2.20081}\end{array}$ \\
\hline
\end{tabular}

\title{
Fungsi Corporate social responsibility (CSR) Dalam Pengembangan dan Pemberdayaan Masyarakat
}

\author{
Rahmadani ${ }^{1}$, Santoso Tri Raharjo², Risna Resnawaty ${ }^{3}$ \\ 1Program Studi IImu Kesejahteraan Sosial, Fakultas IImu Sosial dan IImu Politik, \\ Universitas Padjadjaran \\ rahmadani15001@unpad.ac.id \\ 2Pusat Studi CSR, Kewirausahaan Sosial dan Pengembangan Masyarakat, Universitas Padjadjaran \\ santoso.tri.raharjo@unpad.ac.id \\ ${ }^{3}$ Program Studi IImu Kesejahteraan Sosial, Fakultas IImu Sosial dan IImu Politik, \\ Universitas Padjadjaran \\ risna.resnawaty@unpad.ac.id
}

\begin{abstract}
ABSTRAK
Corporate social responsibility merupakan salah satu bentuk kepatutan yang diberikan oleh perusahaan kepada masyarakat yang berada di sekitar perusahaan. Adanya tanggungjawab sosial perusahaan ini dapat memberikan sebuah perubahan positif di dalam kehidupan masyarakat atau komunitas. Pelaksanaan program corporate social responsibility oleh perusahaan seharusnya dapat memunculkan kemandirian masyarakat, karena dalam corporate social responsibility sendiri terdapat tipe implementasi pemberdayaan. Oleh sebab itu, perusahaan perlu mengedepankan program corporate social responsibility yang dapat meningkatkan kemandirian dan meningkatkan kesejahteraan masyarakat yang menjadi sasaran dalam target program. Pemberdayaan masyarakat menjadi salah satu upaya dan metode yang dapat digunakan oleh perusahaan dalam menciptakan kondisi masyarakat yang aktif, partisipatif dan mandiri. Hal ini dikarenakan dalam pemberdayaan masyarakat mendorong terciptanya masyarakat yang aktif dan partisipatif untuk mencapai tujuan yang ingin dicapai. Dengan demikian, jika sebauh perusahaan merancang program-program corporate social responsibility yang bertujuan untuk memandirikan masyarakat maka perusahaan harus menggunaka metode pemberdayaan masyarakat agar tercapainya pelaksanaan program corporate social responsibility yang membuat masyarakat menjadi berdaya, mandiri dan tidak ketergantungan.
\end{abstract}

Kata Kunci: Tanggung J awab Sosial Perusahaan; Pengembangan Masyarakat; Kemandirian Masyarakat

\section{ABSTRACT}

Corporate social responsibility is one form of propriety provided by companies around the company. The existence of corporate social responsibility can provide positive responsibility in the life of the community or community. Implementing corporate social responsibility programs by companies that can bring about community independence, because in corporate social responsibility itself there is implementation of empowerment. Therefore, companies need to prioritize corporate social responsibility programs that can increase independence and improve the ability of the people who are targeted in the target program. Community empowerment is one of the efforts and methods that can be used by companies in creating conditions for an active, participatory and independent society. This is because in community empowerment the creation of an active and participatory community to achieve the goals to be achieved. Thus, if a company is adjusted to corporate social responsibility programs that aim to empower the community, the company must use the method of community empowerment to achieve the implementation of corporate social responsibility programs that make the community empowered, independent and not dependent.

Keywords: Corporate social responsibility; Community Development; Community Independence 


\begin{tabular}{|c|c|c|c|c|}
\hline Share: Social Work Jurnal & VOLUME: 8 & NOMOR: 2 & HALAMAN: $203-210$ & $\begin{array}{c}\text { ISSN: 2339-0042 (p) } \\
\text { ISSN: 2528-1577 (e) } \\
\text { Doi: 10.24198/share.v8i2.20081 }\end{array}$ \\
\hline
\end{tabular}

\section{PENDAHULUAN}

Corporate social responsibility atau lebih familiar dikenal dengan istilah CSR atau tanggung jawab sosial perusahaan merupakan salah satu esensi yang harus diberikan oleh perusahaan kepada lingkungan sosial dimana sebuah perusahaan berada. Secara konseptual, definisi Corporate Sosial resposibility dapat disimpulkan sebagai tanggung jawab sosial perusahaan untuk menciptakan keseimbangan kondisi sosial, ekonomi dan lingkungan dimana perusahaan berada. Tanggung jawab sosial perusahaan pada umumnya merupakan tanggung jawab moral yang harus dibayarkan oleh perushaan kepada para stakeholder yang ada dalam perusahaan, komunitas atau masyarakat serta ekologi/lingkungan. Dengan demikian adanya sebuah perusahaan harus dapat memberikan dampak dan tanggung jawab sosial bagi stakeholder, masyarakat dan lingkungan dimana perusahaan beroperasi.

Pada pelaksanaannya Corporate social responsibility diharapkan dapat memberikan perubahan dalam kehidupan sosial yang ada di masyarakat. Penerapan corporate social responsibility mampu bersinergi untuk menciptakan keseimbangan antara kondisi sosial, ekonomi dan masyarakat dimana perusahaan beroperasi. Sehingga dalam pelaksanaannya, program corporate social responsibility harus memperhatikan pada prinsip triple bottoms lines, dimana prinsip tersebut menyangkung 3 aspek yang telah dibahas sebelumnya yaitu, finasial, sosial dan lingkungan. Dengan adanya sinergisasi pada ketiga aspek tersebut dapat menciptakan keberlanjutan dunia perusahaan yang lebih baik serta menciptakan hubungan yang harmonis antara perusahaan dengan stakeholder dan komunitas/ masyarakat.

Hadirnya dunia perusahaan atau industri di tengah-tengah kehidupan masyarakat, diharapkan dapat memberikan kontribusi terhadap peningkatan kualitas hidup dan tingkat kesejahteraan masyarakat. Melalui program corporate social responsibility sebuah perusahaan, perusahaan dapat memberikan pelayanan, bantuan bahkan pemberdayaan kepada masyarakat melalui tanggung jawab soial guna meningkatkan kualitas hidup dan tingkat kesejahteraan hidup masyarakat. Sehingga pada pelaksanaanya program corporate social responsibility diharapkan dapat meningkatkan dan menciptakan kemandirian pada masyarakat melalui program-program corporate social responsibility yang diusung oleh perusahaan.

Pemberdayaan atau pengembangan masyarakat merupakan salah satu upaya yang dapat dilakukan oleh perusahaan untuk dapat meningkatkan taraf hidup dan kesejahteraan masyarakat. Pengembangan dan pemberdayaan manjadi salah satu upaya yang dapat dilakukan oleh perusahaan untuk meningkatkan kesejahteraan hidup masyarakat, dikarenakan pada hakikatnya pengembangan masyarakat menekankan pada partisipasi masyarakat. Oleh sebab itu perusahaan melalui program corporate social responsibility pengembangan dan pemberdayaan masyarakat diharapkan dapat menciptakan kesejahteraan hidup dan kemandirian di dalam masyarakat.

Berbicara mengenai kemandirian masyarakat melalui tanggung jawab sosial perusahaan, kemandirian masyarakat muncul dikarenakan adanya upaya yang sustainabled berkelanjutan yang dilakukan oleh perusahaan. Kemandirian masyarakat dibentuk melalui partisipasi aktif dan keterlibatan masyarakat dalam membentuk rancangan kegiatan dan pelaksanaan, agar masyarakat dan perusahaan mengetahui apa yang menjadi kebutuhan masyarakat, bukan berdasarkan pada keinginan. Oleh sebab itu, dalam hal ini corporate social responsibility sebuah perusahaan diharapkan dapat melibatkan masyarakat dalam upaya pengembangan dan pemberdayaan masyarakat, guna menciptakan tanggung jawab sosial perusahaan yang mendorong terwujudnya peningkatan taraf hidup dan kesejahteraan masyarakat serta menciptakan kemadirian di dalam masyarakat.

\section{METODE}

Penulisan artikel ini menggunakan pendekatan jenis penelitian deskriptif. Metode yang digunakan dalam penelitian ini adalah metode penelitian deskriptif dengan kecenderungan untuk menggambarkan secara ringkas mengenai berbagai kondisi, berbagai situasi, serta berbagai fenomena terkait dengan tanggung jawab sosial perusahaan/ corporate social responsibility terhadap pengembangan masyarakat berdasarkan perspektif pekerjaan sosial.

Metode yang digunakan dalam penulisan artikel ini adalah metode studi literatur atau studi pusaka. Studi Kepustakaan yaitu mengadakan penelitian dengan cara mempelajari dan membaca literatur-literatur yang ada hubungannya dengan permasalahan yang menjadi obyek penelitian.

Sehingga studi kepustakaan atau studi literatur merupakan sebuah metode penelitian yang dilakukan dengan cara mengumpulkan data, konsep, teori dan kajian-kajian terkait dengan fenomena yang dibahas dalam artikel ini yaitu konsep, teori, kajian-kajian yang terkait dengan 


\begin{tabular}{|c|c|c|c|c|}
\hline Share: Social Work Jurnal & VOLUME: 8 & NOMOR: 2 & HALAMAN: 203-210 & $\begin{array}{c}\text { ISSN: 2339-0042 (p) } \\
\text { ISSN: 2528-1577 (e) } \\
\text { Doi: 10.24198/share.v8i2.20081 }\end{array}$ \\
\hline
\end{tabular}

fenomena dan permasalahan mengenai tanggung jawab sosial perusahaan terhadap penembangan masyarakat berdasarkan pada perspektif pekerjaan sosial.

\section{HASI L DAN PEMBAHASAN}

\section{a. Corporate social responsibility}

CSR adalah merupakan janji dan komitmen perusahaan dalam dunia bisnis untuk memberikan kontribusinya dalam upaya menciptakan pengembangan ekonomi yang sifatnya berkelanjutan dengan memperhatikan tanggung jawab sosial perusahaan serta menitikberatkan pada keseimbangan pada aspek sosial, ekonomi dan lingkungan tempat perusahaan berada (Rahrajo, 2015. Dalam praktiknya, pelaksanaan corporate social responsibility terdapat tiga motif yang melatarbelakangi keterlibatan perusahaan dalam program corporate social responsibility. Adapun ketiga motif tersebut adalah motif menjaga keamanan fasilitas produksi, motif mematuhi kesepakatan kontrak kerja, dan motif moral untuk memberikan pelayanan sosial pada masyarakat lokal. Sehingga pada pelaksanaanya, corporate social responsibility dilatarbelakangi oleh motif moral sebagai tanggung jawab sosial yang harus diberikan oleh perusahaan terhadap masyarakat tempat perusahaan berada.

Corporate social responsibility juga dapat dipahami sebagai salah satu wujud partisipasi dari perusahaan atau dunia usaha untuk menciptakan pembangunan berkelanjutan dengan mengembangkan program kepedulian perusahaan kepada masyarakat sekitar di sekitar perusahaan melalui penciptaan dan pemeliharaan keseimbangan antara keuntungan, fungsi-fungsi sosial, dan pemeliharaan lingkungan hidup. Dengan artian corporate social responsibility dikembangkan melalui prinsip Tri Bottom Line, dimana prinsip ini menekankan keseimbangan pada aspek sosial, ekonomi, dan lingkungan.

Pendapat lain mengenai corporate social responsibility kembali dikemukakan oleh Sankat dan Clement (2002) dalam Rudito dan Famiola (2007), beliau mengemukakan bahwa corporate social responsibility CSR merupakan komitmen usaha yang dilakukan oleh perusahaan atau badan usaha untuk bertindak secara etis, beroperasi secara legal serta berkontribusi untuk meningkatkan kualitas hidup dari karyawan dan keluarganya, dan perusahaan juga memiliki kewajiban untuk berkontribusi pada peningkatan masyarakat lokal/ komunitas lokal.
Berdasarkan pada pendapat di atas, secara umum corporate social responsibility dapat dipahami sebagai salah satu bentuk kegiatan yang bertujuan untuk meningkatkan kesejahteraan dan kualitas hidup masyarakat melalui peningkatan kemampuan manusia sebagai individu untuk dapat mengembangkan kemampuan dan meningkatkan kapasitas mereka guna mencapai kemandirian dan kulaitas hidup yang lebih baik, seperti yang telah dijelaskan sebelumnya. Selain itu penerapan corporate social responsibility juga dapat dipahami sebagai bentuk atau upaya untuk menjalin hubungan yang harmonis dan dinamis antara masyarakat sekitar perusahaan dengan perusahaan yang berada di tengah-tengah masyarakat melalui program-program dalam tanggung jawab sosial perusahaan.

Dalam pelaksanaan corporate social responsibility, terdapat tiga tingkatan kegiatan yang dapat dilakukan dalam program-program corporate social responsibility. Adapun tiga tingkatan program tersebut adalah, petama charity, charity merupakan salah satu bentuk program tanggung jawab sosial perusahan yang menekankan pada kegiatan yang bersifat charity/ pemberian bantuan yang sifatnya langsung. Kedua adalah philantriphy, tipe kedua ini melaksanaakan kegiatan corporate social responsibility berdasarkan pada penyelesaian dan membantu permaslahan-permaslahan secara parsial, dengan artian tipe ini melaksanakan kegiatan tanggung jawab sosial perusahaan berdasarkan pada permasalahan-permasalahan yang dihadapi oleh masyarakat sekitar perusahaan. Tipe ketiga adalah citizenship, tingkatan kegiatan program tanggung jawab sosial perusahaan ini berorientasi untuk membangun daya saing masyarakat, dengan artian pelaksanaan program berupaya untuk meningkatkan kapasitas masyarakat agar dapat mandiri dan mendapatkan penyelesaian permasalahan yang dihadapi oleh masyarakat itu sendiri.

Ditinjau dari tipe implementasi atau pelaksanaan kegiatan tanggung jawab sosial perusahaan, terdapat tiga tipe pelaksanaan tanggung jawab sosial perusahaan. (Budimanta, dkk dalam santoso tri raharjo, 2018) menjelaskan tiga tipe pelaksanaan kegiatan tanggung jawab sosial perusahaan. Adapun tipe yang pertama adalah Community relations, community relation merupakan tipe pelaksanaan tanggung jawab sosial perusahaan melalui kegiatan-kegiatan yang menyangkut pengembangan kesepahaman antara masyarakat dan perusahaan melalui komunikasi, relasi dan informasi diantara masyarakat, perusahaan dan pihak-pihak terkait. Dalam pelaksanaan tipe ini, 
pelaksanaan tanggung jawab sosial perusahaan cenderung mengarah pada bentuk-bentuk pemberian barang yang sifatnya langsung (charity)

Kedua community services, community servisces merupakan tipe pelaksanaan tanggung jawab sosial perusahaan yang mengedepankan pelayanan kemasyarakatan terhadap masyarakat sekitar perusahaan. Tipe implementasi dari tanggung jawab sosial perusahaan ini berupaya untuk memenuhi kepentingan komunitas atau kepentingan masyarakat. Tipe dari kategori ini biasanya melaksankan pembangunan secara fisik pada sektor-sektor tertentu seperti, kesehatan, keagamaan, pendidikan. Sehingga dalam pelaksanaan tipe ini perusahaan berupaya untuk memberikan kebutuhan yang memang dibutuhkan oleh masyarakat, sehingga permasalahan yang dihadapi oleh komunitas atau masyarakat dapat diatasi melalui program-program perusahaan. Dengan demikian dalam pelaksanaan kegiatan tanggung jawab sosial perusahaan pada tipe community empowering ini menitikberatkan pada keterlibatan masyarakat dalam pelaksanaan kegiatan agar capaian yang ingin dicapai dalam program community empowering dapat dicapai dengan baik dan sesuai dengan kebutuhan masyarakat/komunitas.

Ketiga, community empowering, tipe pelaksanaan dari kegiatan tanggung jawab sosial perusahaan ini memberikan akses yang lebih luas kepada masyarakat guna menigkatkan taraf hidup dan kualitas hidup yang lebih baik kepada komunitas atau masyarakat. Adanya akses yang lebih luas yang diberikan oleh perusahaan ini mampu menunjang kemandirian masyarakat. Masyarakat diberdayakan agar masyarakat dapat meningkatkan kapasitas mereka dalam mengatasi permasalahan yang dihadapi dan meningkatkan dan mengembangkan potensi-potensi yang potensial, yang dapat meningkatkan kualitas hidup masyarakat menjadi lebih baik.

\section{b. Pengembangan dan Pemberdayaan Masyarakat}

Pengembangan masyarakat merupakan sebuah istilah yang terdiri dari dua konsep, yaitu pengembangan dan masyarakat. Sebagaimana dikemukakan oleh Rothman (1995), bahwa pengembangan lebih merujuk pada upaya peningkatan pengetahuan dan keterampilan masyarakat agar kondisi sosial-ekonomi meningkat. Pengembangan masyarakat dapat dilakukan melalui bentuk kegiatan/ usaha bersama dan terencana guna meningkatkan kesejahteraan dan kualitas kehidupan manusia. Sedangkan komunitas atau masyarakat merupakan konsep yang menyatakan tentang sekelompok orang dengan identitas bersama yang diatur dalam sebuah kesatuan sistem sosial yang berlaku di dalamnya (Raharjo, 2015). Sehingga dengan demikian, pengembangan masyarakat sangat bergantung pada pola hubungan dan interaksi antara individu-individu di dalam sebuah komunitas/ masyarakat serta adanya aksi bersama daripada kegiatan individu-individu terhadap perubahan yang lebih baik untuk meningkatkan kualitas hidup dan kesejahteraan masyarakat yang ada di dalam masyarakat itu sendiri.

Dalam pelaksanaan pengembangan masyarakat/ community development terdapat beberapa bidang atau ranah yang dapat menjadi sasaran dalam usaha pengembangan dan pemberdayaan masyararakat. Adapun bidang cakupan yang dapat dilakukan pengembangan dan pemberdayaaan masyarakat biasanya meliputi sektor ekonomi, pendidikan, kesehatan dan sosialbudaya.

Pendapat serupa juga dikemukan oleh United Nation (Raharjo, 2015), yang menyebutkan bahwa pengembangan merupaka proses yang didesain atau dirancang untuk menciptakan perubahan pada kondisi ekonomi dan kemajuan sosial komunitas melalui partisipasi aktif setiap individu masyarakat yang terlibat dalam upaya pengembangan. Sedangkan Pengembangan masyarakat menurut (Warren, 1978) diartikan sebagai sebuah proses atau tahapan untuk membantu masyarakat dalam menganalisa masalah mereka, untuk melaksanakan perubahan yang lebih baik, sehingga masyarakat mempunyai kewenangan/ otonomi terhadap apa yang baik dan layak terhadap masyarakat itu sendiri yang berujung pada kemandirian. Masyarakat yang mandiri sebagai partisipan berarti terbukanya ruang dan kapasitas mengembangkan potensi, mengontrol lingkungan dan sumberdayanya sendiri, menyelesaikan masalah secara mandiri, dan ikut menentukan proses politik di ranah negara. Masyarakat ikut berpartisipasi dalam proses pembangunan dan pemerintahan (Sutoro Eko, 2002).

Berbicara mengenai kemandirian masyarakat merupakan salah satu capaian yang harus dicapai dalam upaya pengembangan dan pemberdayaan masyarakat. Hal ini dikarenakan dalam pemberdayaan masyarakat, individu-individu yang berada di dalam masyarakat memiliki upaya dan usaha untuk mengembangkan diri melalui kegiatan dalam pengembangan yang dilakukan. Adanya pengembangan pengetahuan, wawasan dan 
keterampilan dalam mengenali dan mengatasi masalah serta mengembangkan potensi yang dapat meningkatkan kemandirian dan kualitas hidup yang lebih baik. Dalam Permendagri RI Nomor 7 Tahhun 2007 Pasal 1 ayat 8 tentang Kader Pemberdayaan Masyarakat, dijelaskan bahwa pemberdayaan masyarakat menjadi strategi yang digunakan dalam pembangunan masyarakat sebagai upaya untuk mewujudkan kemampuan dan kemandirian dalam kehidupan bermasyarakat, berbangsa dan bernegara. Dengan demikian dapat dipahami bahwa capaian yang diharapkan dalam pengembangan dan pemberdayaan masyarakat adalah terwujudnya kemandirian di dalam kehidupan masyarakat yang diberdayakan.

Ditinjau dari tujuan Pemberdayaan Masyarakat, Menurut Mardikanto (2014:202), terdapat enam tujuan pemberdayaan masyarakat yaitu:
1. "Perbaikan Kelembagaan $\begin{array}{lll}\text { Institution" Dengan } & \text { perbaikan } \\ \text { kegiatan/tindakan yang dilakukan, }\end{array}$ kegiatan/tindakan yang dilakukan,
diharapkan akan memperbaiki kelembagaan, termasuk pengembangan jejaring kemintraan usaha.

2. Perbaikan Usaha "Better Business" Perbaikan pendidikan "semangat belajar", perbaikan aksesibisnislitas, kegiatan dan perbaikan kelembagaan, diharapkan akan memperbaiki bisnis yang dilakukan.

3. Perbaikan Pendapatan "Better Income" Dengan terjadinya perbaikan bisnis yang dilakukan, diharapkan akan dapat memperbaiki pendapatan yang diperolehnya, termasuk pendapatan keluarga dan masyarakat.

4. Perbaikan Lingkungan "Better Environment" Perbaikan pendapatan diharapkan dapat memperbaiki lingkungan "fisik dan sosial" karena kerusakan lingkungan seringkali disebabkan oleh kemiskinan atau pendapatan yang terbatas.

5. Perbaikan Kehidupan "Better Living" Tingkat pendapatan dan keadaan lingkungan yang membaik, diharapkan dapat memperbaiki keadaan kehidupan setiap keluarga dan masyarakat.

6. Perbaikan Masyarakat "Better Community" Kehidupan yang lebih baik yang didukung oleh lingkungan "fisik dan sosial" yang lebih baik, diharapkan akan terwujud ke kehidupan masyarakat yang lebih baik pula."

Dalam pelaksanaan pemberdayaan atau pengembangan masyarakat terdapat prinsip-prinsip yang harus dijalankan agar tujuan dan sasaran dalam pelaksanaan kegiatan dapat dicapai dengan baik dan dan sesuai dengan harapan. Adapun prinsip-prinsip menurut (Najiati, dkk, 2005:54) prinsip kesetaraan, prinsip pasrtisipasi, keswadayaan atau kemandirian dan serta prinsip berkelanjutan. Berikut dibawah ini akan dijelaskan lebih lanjut mengenai empat prinsip-prinsip dalam pelaksanaan pemberdayaan masyarakat sebagai berikut:

1. "Prinsip kesetaraan

Prinsip utama yang harus diterapkan dalam proses atau kegiatan pemberdayaan masyarakat adalah adanya kesetaraan kedudukan antara masyarakat dengan lembaga yang melakukan program-program pemberdayaan masyarakat, baik laki-laki maupun perempuan. Dinamika yang dibangun dalam pemberdayaan masyarakat adalah adanya hubungan kesetaraan dengan mengembangkan mekanisme berbagai pengetahuan, pengalaman, serta keahlian satu sama lain. Sehingga dalam pelaksanaan nya setiap orang memiliki kesempatan dan hak yang sama dalam upaya pengembangan masyarakat sesuai dengan potensi dan kemampuan yang dimiliki.

2. Prinsip partisipasi

Prinsip partisipasi dalam pelaksanaan kegiatan pemberdayaan masyarakat dapat memunculkan peran aktif dan memberikan stimulasi guna mendorong kemandirian masyarakat melalui program-program yang diberikan dalam pemberdayaan masyarakat. Oleh sebab itu dalam upaya pemberdayaan masyarakat program-program yang dirancang pada dasarnya harus dapat meningkatkan partisipasi aktif melalui peran petugas yang terlibat dalam pelaksanaan kegiatan. Pada akhirnya masyarakat diharapkan mampu mengenali potensi, masalah atau hambatan yang dihadapi, selanjutnya masyarakat dapat mengatasi dan mengembangkan permaslahan dan potensi yang dimiliki melalui perumusan pemecahan permasalahan yang dilakukan oleh masyarakat itu sendiri.

3. Keswadayaan Atau Kemandirian

Prinsip keswadayaan ialah menghargai dan mengedepankan kemampuan masyarakat dari pada bantuan pihak lain. Konsep ini tidak memandang orang miskin sebagai objek yang tidak berkemampuan "the have not", melainkan sebagai subjek yang memiliki kemampuan sedikit "the have little". Mereka memiliki kemampuan untuk menabung 


\begin{tabular}{|c|c|c|c|c|}
\hline Share: Social Work Jurnal & VOLUME: 8 & NOMOR: 2 & HALAMAN: 203 - 210 & $\begin{array}{c}\text { ISSN: } 2339-0042(p) \\
\text { ISSN: } 2528-1577(e) \\
\text { Doi: } 10.24198 / \text { share.v8i2.20081 }\end{array}$ \\
\hline
\end{tabular}

pengetahuan yang mendalam tentang kendala-kendala usahanya, mengetahui kondisi lingkungannya, memiliki tenaga kerja dan kemauan serta memiliki norma-norma bermasyarakat yang sudah lama dipatuhi. Semua itu harus digali dan dijadikan modal dasar bagi proses pemberdayaan. Bantuan dari orang lain yang bersifat materiil harus dipandang sebagai penunjang sehingga pemberian bantuan tidak justru melemahkan tingkat keswadayaannya.

4. Berkelanjutan

Program pemberdayaan perlu dirancang untuk berkelanjutan, sekalipun pada awalnya peran pendamping lebih dominan dibanding masyarakat sendiri. Tapi secara perlahan dan pasti, peran pendamping akan makin berkurang, bahkan akhirnya dihapus, karena masyarakat sudah mampu mengelola kegiatannya sendiri."

Dengan demikian dapat kita pahami bahwasannya pengembangan masyarakat merupakan salah satu upaya untuk menciptakan perubahan dalam masyarakat melalui partisipasi aktif masyarakat. Dalam pelaksanaan kegiatan pemberdayaan masyarakat, masyarakat perlu didorong untuk terlibat aktif pada setiap perumusan kegiatan, agar capaian dari pelaksanaan kegiatan pemberdayaan masyarakat atau komunitas dapat mengatasi permasalahan, mengembangkan potensi yang menghasilkan kemandirian masyarakat. Selain itu dalam pelaksanaan kegiatan pemberdayaan juga perlu memperhatikan prinsip-prinsip seperti yang telah dijelaskan sebelumnya, dengan tujuan dala pelaksanaan kegiatan pemberdayaan, pemberdayaan masyarakat dapat memberikan hasil yang baik dan memuaskan, baik untuk masyarakat maupun untuk penyelenggara kegiatan pemberdayaan.

\section{c. Fungsi Corporate social responsibility Dalam Pengembangan dan Pemberdayaan Masyarakat}

Soerjono Soekanto (1997) mengemukakan bahwa fungsi merupakan sekumpulan peran yang dapat dilakukan oleh organisasi atau kelompok tertentu yang ditujukan guna mencapai tujuan tertentu pula. Mengacu kepada penjelasan sebelumnya mengenai corporate social responsibilityl tanggung jawab sosial perusahaan dan pemberdayaan masyarakat, maka kedua konsep tersebut memiliki kaitan yang dinamis guna menciptakan kehidupan dan kesejahteraan hidup yang lebih baik di dalam masyarakat/ komunitas. Hal ini dikarenakan pada kedua konsep tersebut mendorong untuk terciptanya perubahan-perubahan dalam masyarakat menjadi lebih baik (Raharjo, 2015). Kegiatan CSR bagi perusahaan dapat berfungsi sebagai upaya atau pendekatan dalam upaya meningkatkan kondisi sosial masyarakat. Upaya pengembangan dan pemberdayaan melalui kegiatan CSR, dapat ditujukan berdasarkan prioritas (hal paling mendesak) atau kebutuhan utama masyarakat.

Kegiatan tanggung jawab sosial perusahaan semestinya dapat menjadi media atau suatu pendekatan meningkatkan keberdayaan masyarakat. Sebagaimana telah dikemukakan sebelumnya bahwa tipologi kegiatan CSR yaitu community assistant, community relation, dan community empowerment, dapat menjadi strategi pendekatan kepada masyarakat. Coommunity empowerment merupakan salah satu pendekatan CSR yang sangat penting dan strategis dalam meningkatkan kondisi sosial ekonomi masyarakat (Raharjo, 2015). Oleh sebab itu dengan adanya implementasi yang menitikberatkan pada pemberdayaan maka pemberdayaan masyarakat menjadi salah satu media, alat dan cara untuk menciptakan perubahan dalam masyarakat melalui program corporate social responsibility dalam pemberdayaan masyarakat.

Merujuk kepada konsep pemberdayaan yang menekankan pada partisipasi aktif masyarakat dalam setiap kegiatan dapat diimplementasikan dalam pelaksanaan program corporate social responsibility. Hal ini dikarenakan pelaksanaan program corporate social responsibility yang ideal adalah mampu menciptakan kemandirian masyarakat dan menciptakan perubahan serta meningkatkan kualitas hidup masyarakat yang lebih baik. Oleh sebab itu untuk mencapai tujuan yang ideal tersebut, maka pemberdayaan masyarakat dapat menjadi salah satu cara yang digunakan agar masyarakat dapat berdaya melalui programprogram corporate social responsibility.

Dalam pelaksanaan kegiatan corporate social responsibility perlu melibatkan setiap pihak-pihak terkait guna mencapai hasil capaian yang lebih baik dan sesuai dengan kebutuhan masyarakat sebagai sasaran dalam kegiatan. Adanya keterlibatan pihakpihak terkait ini memberikan upaya pelaksanaan kegiatan berdasarkan pada sudut pandang yang berbeda, sehingga dalam pelaksanaanya dapat dilihat berdasarkan pada pemikiran, ide dan gagasan yang berbeda guna mencapai perumusan hasil yang diinginkan. Adapun pihak-pihak yang sekiranya perlu terlibat dalam pelaksanaan kegiatan corporate social responsibilityini adalah perusahaan 


\begin{tabular}{|c|c|c|c|c|}
\hline Share: Social Work Jurnal & VOLUME: 8 & NOMOR: 2 & HALAMAN: 203-210 & $\begin{array}{c}\text { ISSN: 2339-0042 (p) } \\
\text { ISSN: 2528-1577 (e) } \\
\text { Doi: 10.24198/share.v8i2.20081 }\end{array}$ \\
\hline
\end{tabular}

beserta stakeholder yang terkait, masyarakat, pemerinta dan pihak-pihak yang sekiranya memiliki wewenang, kemampuan untuk menciptakan perubahan yang lebih baik dalam masyarakat melalui pelaksanaan kegiatan corporate social responsibility.

Dengan demikian dalam pelaksanaan corporate social responsibility atau tanggung jawab sosial perusahaan yang menekankan pada kemandirian dan peningkatan pada kualitas hidup yang lebih baik terhadap masyarakat yang menjadi sasaran pelaksanaan program harus memberikan pemberdayaan agar masyarakat berdaya seperti yang terdapat pada tipe implementasi community empowering. Hal ini dikarenakan dalam pelaksanaan pemberdayaan masyarakat, masyarakat perlu didorong. Dilibatkan dan ditingkatkan kemampuan mereka terhadap potensi dan masalah yang dihadapi. Sehingga dalam pelaksanaannya, corporate social responsibility perlu memperhatikan aspek pemberdayaan agar terciptanya masyarakat yang mandiri, tidak ketergantungan, serta terciptanya kesejahteraan masyarakat melalui program corporate social responsibility yang memberdayakan masyarakat.

Profesi pekerjaan sosial merupakan salah satu profesi yang memiliki andil dalam membangun dan menciptakan kesejahteraan dan kualitas hidup masyarakat yang lebih baik. Dalam konteks corporate social responsibility, pekerja sosial dapat berperan sebagai community worker dalam pemberdayaan masyarakat melalui programprogram corporate social responsibility perusahaan.

Pekerja sosial dapat berperan sebagai perpanjangan perusahaan kepada masyarakat guna mengkoordinir, mengelola dan menciptakan perubahan dalam masyarakat. Pekerja sosial dalam pelaksanaan program corporate social responsibility perusahaan dapat juga merancang programprogram pemberdayaan yang dapat meningkatkan kemandirian dan kesejahteraan masyarakat. Selain itu juga, pekerja sosial dapat bertindak sebagai pihak yang dapat mengakses pihak-pihak yang dapat menciptakan perubahan dalam masyarakat melalui program-program yang dilaksanakan

\section{SI MPULAN}

Corporate social responsibilityatau tanggung jawab sosial perusahaan merupakan salah satu bentuk etika perusahaan terhadap masyarakat. Tanggung jawab sosial perusahaan dapat menjadi peluang bagi masyarakat untuk menciptakan perubahan dan peningkatan kualitas hidup yang lebih baik dengan adanya kehadiran perusahaan ditengah-tengah masyarakat. Pemberdayaan masyarakat menjadi salah satu upaya yang dapat dilakukan dalam menciptakan perubahan dalam masyarakat. Oleh sebab itu pelaksanaan program corporate social responsibility perlu menciptakan kemandirian dan peningkatan hidup masyarakat, sehingga dalam implementasi kegiatan program corporate social responsibility perlu menggunakan metode pemberdayaan dan pengembangan masayarakat. Hal ini dikarenaka dalam pengembangan dan pemberdayaan masyarakat, masyarakat perlu didorong, ditingkatkan kemampuan dan kapasiatas mereka, serta perlu keterlibatan masyarakat yang aktif dan partisipatif untuk mencapai perubahan yang diinginkan melalui pemberdayaan.

Dengan demikian dapat disimpulkan bahwa, pelaksanaan program corporate social responsibility atau tanggung jawab sosial perusahaan dapat memiliki peranan penting dalam masyarakat di sekitar perusahaan apabila program yang dirancang dapat meningkatkan kapasitas, pengetahuan serta kesejahteraan masyarakat menjadi lebih baik. Oleh sebab itu maka perusahaan selaku pembuat program dan kebijakan atas pelaksanaan program corporate social responsibility diharapkan mampu untuk menyelenggarakan program-program corporate social responsibility yang memberdayakan masyarakat. Karena dalam pemberdayaan masyarakat, masayarakat didorong untuk terlibat aktif fan partisipatif dalam mengenali potensi dan maslaah untuk mencapai tujuan yang lebih baik.

\section{DAFTAR PUSTAKA}

Andi Mapisangka. 2009. Implementasi CSR terhadap Kesejahteraan Hidup Masyarakat. J ESP Vol. 1, No. 1

ASY'ARI, HASAN. 2009. IMPLEMENTASI CORPORATE SOCIAL RESPONSIBILITY (CSR) SEBAGAI MODAL SOSIAL PADA PT NEWMONT. Tesis. Program Studi Magister IImu Hukum, Program Pasca Sarjana Universitas Diponegoro Semarang

Bambang Rudito dan Melia Famiola. 2007. Etika Bisnis dan Tanggung Jawab Sosial Perusahaan di Indonesia. Bandung: Rekayasa Sains Bing Bedjo Tanudjaja. PERKEMBANGAN CORPORATE SOCIAL RESPONSIBILITY DI INDONESIA. J urusan Desain Komunikasi Visual, Fakultas Seni dan Desain, Universitas Kristen Petra Surabaya 


\begin{tabular}{|c|c|c|c|c|}
\hline Share: Social Work Jurnal & VOLUME: 8 & NOMOR: 2 & HALAMAN: 203-210 & $\begin{array}{c}\text { ISSN: 2339-0042 (p) } \\
\text { ISSN: 2528-1577 (e) } \\
\text { Doi: 10.24198/share.v8i2.20081 }\end{array}$ \\
\hline
\end{tabular}

Cholisin. 2011. PEMBERDAYAAN MASYARAKAT. Diakses

dari

http://staffnew.uny.ac.id/upload/131474

282/pengabdian/PEMBERDAYAAN+MASY ARAKAT.pdf. Pada 17 November 2018, pukul 06.32 WIB

Erna. 2015. PENGEMBANGAN MASYARAKAT AGRIBISNIS DEFINISI PENGEMBANGAN MASYARAKAT, PENDEKATAN PROFESIONAL DAN PENDEKATAN RADIKAL. FAKULTAS PERTANIAN UNIVERSITAS HALU OLEO KENDARI

Firdaus, Corporate Social Responsbility, Juranal IImiah Hukum, Fakultas Hukum Universitas Riau, Edisi 1, No.1.2010.

Hendrik Budi Untung, Corporate Social Responsbility, Sinar Grafika, Jakarta, 2008.

Lina Anatan. CORPORATE SOCIAL RESPONSIBILITY (CSR): Tinjauan Teoritis dan Praktik di Indonesia. Staff Pengajar Fakultas Ekonomi Universitas Kristen Maranatha

Mulyadi, Pengelolaan Program Corporate social responsibility. Pendekatan, keperpihakan, dan Keberlanjutan, Center For Population Studies, UGM, 2003.

Muryati, Dewi Tutri., SH, Tanggungjawab Sosial Perusahaan Dalam Kaitanya Dengan Kebijakan Lingkungan Hidup, Jurnal Law Reform, Pembaharuan Hukum, Volume 3/No. 1 Februari 2007, Program Magister IImu Hukum, Universitas Diponegoro, Semarang.

Poewanto. 2010. Corporate social responsibility, Pustaka pelajar: Yogyakarta

Raharjo, ST. 2015. C S R: Relasi Dinamis anatara Perusahaan Multinasional Ddengan Masyarakat Lokal. Unpad Press

Rothman. 2015. Community Develepment and Comminty Organtization: Strategies and Technique.Prentice Hall: New York

Siregar, Chairil. N., Analisis Sosiologis Terhadap Implementasi CSR pada Masyarakat Indonesia, Jurnal Sosioteknologi Edisi 12 tahun 06, Desember 2007, ITB, BandungSulistyaningtyas, I. D. 2006. Tanggung Jawab Sosial Perusahaan dalam Program Kampanye Sosial. Jurnal IImu Komunikasi, Vol. 3 No. 1, 63-76.
Suharto, Ign. 2010. Pengaruh Program Pengembangan Masyarakat terhadap Kemampuan Masyarakat Meningkatkan Kesejahteraannya di Desa Padaawas, Kecamatan Pasinwangi, Kabupaten Garut (Studi Program Pengembangan Masyarakat di Kawasan Pembangkit Listrik tenaga Panas Bumi PT. Chevron).FISIP Unpad.

Umar Hasan. Kewajiban Corporate social responsibility (CSR) Dilihat Dari Perspektif Hukum. Majalah Hukum Forum Akademika 